\title{
Analisis Kepuasan Pelanggan Terhadap Kualitas Batako Dengan Menggunakan Metode Taguchi -Kano
}

\author{
Widy Setyawan ${ }^{1}$, Iman Saefurrohman ${ }^{2}$, \\ ${ }^{1,2}$ Teknik Industri Universitas Suryakancana \\ Jl Pasir Gede Raya, Cianjur \\ ${ }^{1}$ widy_setyawan@yahoo.com \\ 2 imansaefurrohman@gmail.com
}

Dikirimkan:09, 2018. Diterima: 10,2018. Dipublikasikan: 10,2018.

\begin{abstract}
Quality is one thing that is important in the face of competition in the industry. An industry that can produce a product or service with good quality have a greater opportunity to compete. Customer satisfaction is the most important thing to know if the quality of a product can be accepted in the market or not, the customer satisfaction in the mean is how the compressive strength and absorption of tiles made at the plant WS is already in line with consumer expectations or not. This study aims to mengeathui customers are satisfied or not with the quality of bricks produced. The method used in this study using a model Kano with the results, test the validity of the first statement obtained $r$ count of 0471 and the value of $r$ table at 0294. reliability test results with Crombach's Alpha 0709 of $13 \mathrm{~N}$ of the item. Kano categorization results obtained category I (indifferent) and $R$ (Reverse), which means indefferent is neutral, the dimensions of Reliability quality brick is good but it would be nice if it improved again. And on the dimensions showed Responsive service and the level of customer satisfaction with quality brick beraada at the level of $R$ (Reverse), which means a setback, at this level that the quality of tiles made the necessary level.
\end{abstract}

Keywords : Taguchi, Costumer Statisfaction, Kano Models

\begin{abstract}
Abastrak - Kualitas merupakan salah satu hal yang penting di dalam menghadapi persaingan dalam dunia industri. Suatu industri yang dapat menghasilkan suatu produk ataupun jasa dengan kualitas yang baik memiliki kesempatan yang lebih besar untuk bersaing. Kepuasan pelanggan merupakan hal yang paling penting untuk mengetahui apakah kualitas suatu produk dapat diterima dipasaran atau tidak, Kepuasan pelanggan yang di maksud adalah bagaimana kuat tekan dan daya serap batako yang ada di pabrik WS apakah sudah sesuai dengan harapan konsumen atau belum. Penelitian ini bertujuan untuk mengeathui pelanggan merasa puas atau tidak dengan kualitas batako yang di hasilkan. Metode yang digunakan pada penelitian ini menggunakan model Kano dengan hasil, uji validitas pada pernyataan pertama diperoleh $r$ hitung sebesar 0.471 dan nilai $r$ tabel sebesar 0.294. hasil uji reliabilitas dengan Crombach's Alpha 0.709 dari $13 \mathrm{~N}$ of item. Hasil pengkategorian Kano didapat kategori I (Indefferent) dan R (Reverse) yang berarti Indefferent yaitu netral, pada dimensi Reliability kualitas batako sudah bagus namun akan lebih bagus apabila ditingkatkan lagi. Dan pada dimensi Responsive menunjukan pelayanan dan tingkat kepuasan konsumen terhadap kualitas batako beraada pada level $\mathrm{R}$ (Reverse) yang berarti kemunduran, pada tingkat ini bahwa kualitas batako yang dihasilkan perlu ditigkatakn.
\end{abstract}

Kata kunci : Taguchi, Kepuasan pelanggan, Model Kano.

\section{Pendahuluan}

\subsection{Latar Belakang}

Dewasa ini kualitas merupakan salah satu hal yang penting di dalam menghadapi persaingan yang ketat dalam dunia industri. Suatu industri yang dapat menghasilkan suatu produk ataupun jasa dengan kualitas yang baik memiliki kesempatan yang lebih besar untuk memenangkan persaingan. Hal ini disebabkan karena saat ini konsumen sudah memiliki kesadaran akan pentingnya kualitas di dalam memilih suatu produk atau jasa. Kenyataan inilah yang menjadi salah satu pendorong bagi dunia industri untuk meningkatkan kualitas dari produk atau jasa yang dihasilkan agar dapat menarik konsumen. Untuk merealisasikan hal tersebut di atas, maka pengendalian kualitas secara mutlak harus dilaksanakan dalam dunia industri agar dapat menghasilkan produk atau jasa yang berkualitas 
sehingga dapat memenuhi kebutuhan dan harapan konsumen. Untuk memenuhi kebutuhan dan harapan konsumen maka batako yang dihasilkan harus sesuai dengan Standar Nasional Indonesia. Batako merupakan bahan bangunan yang berupa bata cetak alternatif pengganti batu bata yang tersusun dari komposisi antara pasir, kapur dan air, yang digunakan untuk pemasangan dinding. Pada saat ini batako sudah sering digunakan sebagai bahan bangunan. Maka dari itu kualitas batako yang digunakan sebagai bahan bangunan harus mempunyai kualitas yang bagus yang dapat mempertahankan kekuatan bangunan yang ada.

Kualitas yang dimaksud adalah kuat tekan dan daya serap air yang dihasilkan harus sesuai dengan syarat-syarat SNI (Standar Nasional Indonesia) yang telah di tentukan, standar yang digunakan saat ini yaitu SNI 03-0349-1989.

\subsection{Perumusan Masalah}

Adapun rumusan masalah dari penelitian ini adalah bagaimana hasil perbaikan kualitas batako dengan menggunakan metode taguchi - kano terhadap kepuasan pelanggan serta sejauhmana hasil analisis dari penggabungan kedua metode diatas.

\subsection{Tujuan Penelitian}

Tujuan yang ingin di capai penelitian ini adalah untuk mengetahui hasil kualitas batako terhadap kepuasan pelanggan dengan menggunakan metode taguchi-kano serta untuk mengetahui hasil analisis dari penggabungan kedua metode tersebut.

\section{Metodologi Penelitian}

Studi Literatur dilakukan untuk mendukung penyelesaian proses pengumpulan dan pengolahan data dalam penelitian ini.

Studi lapangan dilakukan di TB. WS, bertujuan untuk mengetahui kondisi awal perusahaan, serta memahami proses produksi pembuatan Batako. Pengolahan data penelitian dilakukan dalam beberapa tahap yaitu:

1. Identifikasi karakteristik kualitas

2. Menentukan Faktor Kontrol dan Noise

3. Menentukan Setting Level Faktor

4. Menentukan Fungsi Objektif (S/N Ratio)

5. Mengidentifikasi Faktor Kontrol yang Mungkin Berinteraksi

6. Membuat Orthogonal Array

7. Menjalankan Eksperimen

8.Menentukan Faktor yang Berpengaruh Signifikan Terhadap nilai rata-rata dengan Menggunakan Analysis of Variance (ANOVA).

9. Grafik Main Effect Factor
10. Menganalisis Hasil Eksperimen

11. Melakukan Eksperimen Konfirmasi

12. Perhitungan Loss Function

13. Perhitungan Persentase Perbaikan

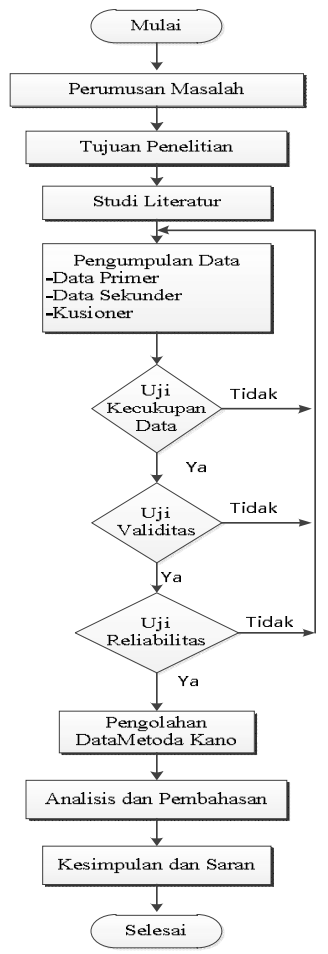

Gambar 1. Kerangka Penelitian

\section{Hasil Penelitian dan Pembahasan}

Berdasarkan pengumpulan dan pengolahan data, didapatkan hasil sebagai berikut.

\section{A. Hasil Pengolahan Data dengan Metode Taguchi}

1. Identifikasi karakteristik kualitas

Karakterisitik kualitas yang diukur adalah kuat tekan (satuan $\mathrm{kg} / \mathrm{cm}^{2}$ ) dan daya serap air (satuan \%). Karena hal ini disesuaikan dengan Standar Nasional Indonesia (SNI) yang telah di tentukan SNI 03-0349-1989 seperti yang tercantum pada Tabel 1.

2. Menentukan Faktor kontrol dan Noise

Identifikasi faktor-faktor yang mempengaruhi karakteristik kualitas diperoleh melalui studi pustaka dan brainstorming dengan pihak pegawai, yaitu dengan menanyakan kepada yang ahli mengenai faktor-faktor apa saja yang mempengaruhi karakteristik batako. Faktor-faktor dapat diidentifikasi dengan menggunakan diagram fishbone seperti pada gambar 2 .

TABEL I 


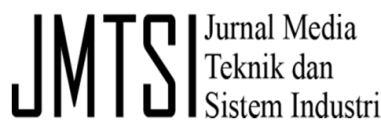

STANDAR DAYA SERAP DAN KUAT TEKAN

\begin{tabular}{|c|c|c|c|c|c|}
\hline \multirow{2}{*}{ Jenis } & \multirow{2}{*}{ Satuan } & \multicolumn{5}{|c|}{ Tingkat Mutu } \\
\cline { 3 - 6 } & & $\mathrm{I}$ & $\mathrm{II}$ & $\mathrm{III}$ & $\mathrm{IV}$ \\
\hline Kuat Tekan & $\mathrm{kg} / \mathrm{cm}^{2}$ & 90 & 65 & 35 & 21 \\
\hline Daya Serap & $\%$ & 25 & 35 & - & - \\
\hline
\end{tabular}

Sumber : SNI 03-0349-1989
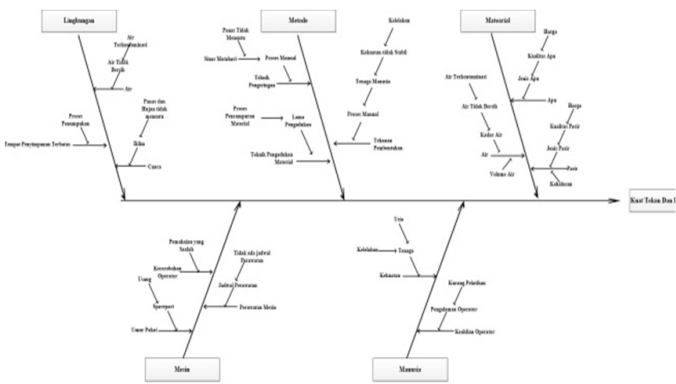

Gambar 2. Diagram Fishbone Faktor Kontrol dan Noise (Sumber : Pengolahan Data 2016)

3. Menentukan Setting Level Faktor

Eksperimen yang dilakukan menggunakan dua setting level yang menunjukkan level tinggi dan rendah. Setting level untuk faktor-faktor yang dilibatkan dalam eksperimen, tabel 2 menunjukan adalah tabel penugasan setting level faktor untuk eksperimen taguchi.

TABEL II

PENENTUAN SETTING LEVEL FAKTOR KONTROL

\begin{tabular}{|c|l|c|c|}
\hline \multirow{2}{*}{ Faktor Kontrol } & \multirow{2}{*}{ Keterangan } & \multicolumn{2}{|c|}{ Level Faktor } \\
\cline { 3 - 4 } & & 1 & 2 \\
\hline A & Lama Adukan & 5 Menit & 10 Menit \\
\hline B & Tekanan & $60 \mathrm{~kg}$ & $120 \mathrm{~kg}$ \\
\hline C & Air & $10 \%$ & $15 \%$ \\
\hline D & lama Pengeringan & 4 hari & 8 hari \\
\hline E & Komposisi (Pasir : kapur) & $1 ; 0,5$ & $1 ; 0,25$ \\
\hline
\end{tabular}

4. Menentukan Fungsi Objektif (S/N Ratio)

Fungsi objektif yang digunakan adalah higher is better untuk kuat tekan karena semakin besar kuat tekan yang di dapat maka semakain bagus kualitas yang dihasilkan dan smaller is better untuk daya serap karena semakin kecil daya serap yang di hasilkan maka semakin bagus kualitas yang dihasilkan.

5. Mengidentifikasi Faktor Kontrol yang Mungkin Berinteraksi

Berikut pada tabel 3 merupakan tabel interaksi antara faktor A dan B untuk kuat tekan.
TABEL III

INTERAKSI ANTARA FAKTOR A DAN FAKTOR B KUAT

\begin{tabular}{|c|c|c|c|c|c|c|}
\hline & & \multicolumn{5}{|c|}{ TEKAN } \\
\hline & & \multicolumn{4}{|c|}{ B } & \multirow{2}{*}{ TOTAL } \\
\hline & & \multicolumn{2}{|c|}{1} & \multicolumn{2}{|c|}{2} & \\
\hline \multirow{2}{*}{ A } & 1 & 56,25 & 60 & 54 & 52 & 222,25 \\
\hline & 2 & 58,9 & 60 & 58,2 & 52,5 & 229,6 \\
\hline \multicolumn{2}{|c|}{ TOTAL } & \multicolumn{2}{|c|}{235.15} & \multicolumn{2}{|c|}{216,7} & 451,85 \\
\hline
\end{tabular}

Sumber : Pengolahan Data 2016

Data interaksi di atas diolah dengan Uji ANOVA 2 arah interaksi dengan menggunakan software SPSS.

Tabel 4 menunjukan hasil perhitungan Nilai $F$ untuk Faktor A dan B Kuat tekan

TABEL IV

PERhitungan Nilai F UNTUK FAKTOR A DAN B KUAT TEKAN

\begin{tabular}{|c|c|c|c|c|}
\hline Source & Sum of Squares & $\mathrm{df}$ & Mean Square & $\mathrm{F}$ \\
\hline Faktor A & 6,735 & 1 & 6,753 & 1,044 \\
\hline Faktor B & 42,55 & 1 & 42,55 & 6,576 \\
\hline Faktor A* Faktor B & 525 & 1 & 525 & 81 \\
\hline Error & 25,881 & 4 & 6,47 & \\
\hline Total & 25596,763 & 8 & & \\
\hline Corrected Total & 75,71 & 7 & & \\
\hline & & & & \\
\hline
\end{tabular}

Sumber : Pengolahan Data 2016

Struktur hipotesis

Ho =Adanya Pengaruh yang signifikan

$\mathrm{H} 1$ =Tidak ada pengaruh yang signifikan

[Ho】_ $((\mathrm{A} \& \mathrm{~B}))=$ Ada interaksi antar faktor

『H1】_((A \&B))=Tidak ada interaksi antar faktor

Wilayah kritis

Untuk Faktor A

$\mathrm{v} 1=1$ (derajat kebebasan kolom)

$\mathrm{v} 2=4$ (derajat kebebasan error)

f_ $(\mathrm{a}(1,4))=7,71$ (dari F tabel )

Gambar 3. Wilayah Kritis Faktor A untuk Faktor B

$\mathrm{v} 1=1$ (derajat kebebasan kolom)

v2 $=4$ (derajat kebebasan error)

f_ $(\mathrm{a}(1,4))=7,71$ (dari F tabel ) 


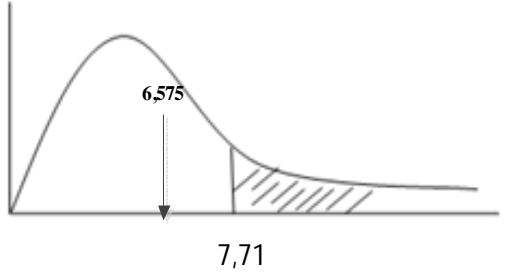

Gambar 3 Wilayah Kritis Faktor B

Untuk Faktor A dan B

$v 1=1$ (derajat kebebasan kolom)

$v 2=4$ (derajat kebebasan error)

$f_{a(1,4)}=7,71$ (dari F tabel)

Gambar 4. Wilayah Kritis Faktor A dan B

Keputusan dan Kesimpulan

Faktor A = Tolak Ho bahwa tidak ada pengaruh dari lama pengadukan

Faktor B = Tolah Ho bahwa tidak ada pengaruh dari tekanan pembentukan

Interaksi A dan B = Tolak Ho bahwa tidak ada interaksi antara faktor A dan B

Untuk perhitungan interaksi antara Faktor A dan B untuk daya serap lakukan langkah perhitungan sama dengan kuat tekan

Diperoleh kesimpulan dari hasil perhitungan interaksi antara dua faktor dengan ANOVA dua arah sebagai berikut :

Untuk kuat tekan

a. Adanya pengaruh dari faktor A (Lama adukan)

b. Adanya pengaruh dari faktor B (Tekanan)

c. Adanya pengaruh dari faktor C (Air)

d. Adanya pengaruh dari faktor $\mathrm{D}$ (pengeringan)

e. Adanya pengaruh dari faktor E (Komposisi pasir dan kapur)

f. Adanya interaksi dari faktro B (Tekanan) dan E (Komposisi pasir dan kapur)

g. Adanya interaksi dari faktor C (Air) dan D (Pengeringan)

6. Membuat Orthogonal Array

Tabel 5 berikut ini merupakan derajat kebebasan faktor kontrol.
TABEL V

DERAJAT KEBEBASAN Derajat Kebebasan

\begin{tabular}{|c|c|c|c|}
\hline \multicolumn{4}{|c|}{ Derajat Kebebasan } \\
\hline Kuat Tekan & \multicolumn{2}{c|}{ Daya Serap } \\
\hline A & 1 & A & 1 \\
\hline B & 1 & B & 1 \\
\hline C & 1 & C & 1 \\
\hline D & 1 & D & 1 \\
\hline E & 1 & E & 1 \\
\hline B \&E & 1 & C\&D & 1 \\
\hline C\&D & 1 & C\&E & 1 \\
\hline Total & 7 & Total & 7 \\
\hline
\end{tabular}

Sumber : Pengolahan Data 2016

Berdasarkan hasil perhitungan di atas maka diperoleh derajat kebebasan sebanyak 7, maka matriks orthogonal array yang dipilih adalah L8.

TABEL VI

ORTHOGONAL ARRAY EKSPERIMEN

\begin{tabular}{|c|c|c|c|c|c|c|c|}
\hline \multirow{2}{*}{ TrialNolo } & \multicolumn{7}{|c|}{ ORTHOGONAL ARRAY EKSPERIMEN } \\
\cline { 2 - 8 } & 1 & 2 & 3 & 4 & 5 & 6 & 7 \\
\hline 1 & 1 & 1 & 1 & 1 & 1 & 1 & 1 \\
\hline 2 & 1 & 1 & 1 & 2 & 2 & 2 & 2 \\
\hline 3 & 1 & 2 & 2 & 1 & 1 & 2 & 2 \\
\hline 4 & 1 & 2 & 2 & 2 & 2 & 1 & 1 \\
\hline 5 & 2 & 1 & 2 & 1 & 2 & 1 & 2 \\
\hline 6 & 2 & 1 & 2 & 2 & 1 & 2 & 1 \\
\hline 7 & 2 & 2 & 1 & 1 & 2 & 2 & 1 \\
\hline 8 & 2 & 2 & 1 & 2 & 1 & 1 & 2 \\
\hline
\end{tabular}

Sumber : Pengolahan Data 2016

7. Menjalankan Eksperimen

Dibawah ini merupakan hasil eksperimen yang diperoleh sebagai berikut:

a) Kuat Tekan

Hasil orthogonal array dari eksperimen kuat tekan seperti yang tercantum pada tabel 7 .

b) Daya Serap

Hasil orthogonal array dari eksperimen daya serap seperti yang tercantum pada tabel 8 .

TABEL VII

\begin{tabular}{|c|c|c|c|c|c|c|c|c|c|}
\hline \multirow{2}{*}{ Trial No } & \multicolumn{7}{|c|}{ Faktor Terkendali } & \multirow{2}{*}{\multicolumn{2}{|c|}{$\begin{array}{c}\text { Hasil Uji } \\
\text { Kuat Tekan }\end{array}$}} \\
\hline & B & E & $\mathrm{BxE}$ & $\mathrm{C}$ & $\mathrm{D}$ & $\mathrm{CxD}$ & A & & \\
\hline 1 & 1 & 1 & 1 & 1 & 1 & 1 & 1 & 48 & 52 \\
\hline 2 & 1 & 1 & 1 & 2 & 2 & 2 & 2 & 56,25 & 58,5 \\
\hline 3 & 1 & 2 & 2 & 1 & 1 & 2 & 2 & 97,5 & 92 \\
\hline 4 & 1 & 2 & 2 & 2 & 2 & 1 & 1 & 82,5 & 91,25 \\
\hline 5 & 2 & 1 & 2 & 1 & 2 & 1 & 2 & 87,5 & 82,5 \\
\hline 6 & 2 & 1 & 2 & 2 & 1 & 2 & 1 & 72 & 68 \\
\hline 7 & 2 & 2 & 1 & 1 & 2 & 2 & 1 & 60 & 62 \\
\hline 8 & 2 & 2 & 1 & 2 & 1 & 1 & 2 & 82,5 & 91 \\
\hline
\end{tabular}

Sumber : Pengolahan Data 2016 
TABEL VIII

ORTHOGONAL ARRAY HASIL EKSPERIMEN DAYA SERAP

\begin{tabular}{|c|c|c|c|c|c|c|c|c|c|}
\hline \multirow{2}{*}{ Trial No } & \multicolumn{7}{|c|}{ Faktor Terkendali } & \multirow{2}{*}{\multicolumn{2}{|c|}{$\begin{array}{c}\text { Hasil Uji } \\
\text { Daya Serap }\end{array}$}} \\
\hline & C & D & $\mathrm{CxD}$ & E & $\mathrm{CxE}$ & A & B & & \\
\hline 1 & 1 & 1 & 1 & 1 & 1 & 1 & 1 & 20 & 17 \\
\hline 2 & 1 & 1 & 1 & 2 & 2 & 2 & 2 & 12 & 11 \\
\hline 3 & 1 & 2 & 2 & 1 & 1 & 2 & 2 & 17 & 14 \\
\hline 4 & 1 & 2 & 2 & 2 & 2 & 1 & 1 & 25 & 20 \\
\hline 5 & 2 & 1 & 2 & 1 & 2 & 1 & 2 & 15 & 13 \\
\hline 6 & 2 & 1 & 2 & 2 & 1 & 2 & 1 & 16 & 14 \\
\hline 7 & 2 & 2 & 1 & 1 & 2 & 2 & 1 & 22 & 18 \\
\hline 8 & 2 & 2 & 1 & 2 & 1 & 1 & 2 & 26 & 20 \\
\hline
\end{tabular}

Sumber : Pengolahan Data 2016

8. Menentukan Faktor yang Berpengaruh Signifikan Terhadap Nilai Rata-rata dengan Menggunakan Analysis of Variance (ANOVA)

Dalam peneletian ini menggunakan higher the better dan smaller the better sehingga rumus yang digunakan adalah sebagai berikut :

$$
\begin{aligned}
& \text { - } \text { higher the better } \\
& \text { S/ } N_{H B}=-10 \log \left(\frac{1}{r} \sum_{i=1}^{r} \frac{1}{y_{1}^{2}}\right) \\
& \text { - smaller the better } \\
& S / N_{S T B}=-10 \log \left(\frac{1}{n} \sum_{i=1}^{n} \frac{1}{y_{1}^{2}}\right)
\end{aligned}
$$

$\underline{\text { Kuat Tekan }}$

Perhitungan Signal Noise Ratio merupakan teknik pemilihan karakteristik mutu yaitu berupa tingkat kekuatan tekan $(\mathrm{kg} / \mathrm{cm} 2)$ dengan fungsi obyeknya Higher The Better (HB), terpilih dalam penghitungan S/NR karena karakteristik kualitas semakin besar nilainya, maka semakin baik. Dalam percobaan ini mempunyai arti bila hasil percobaan mempunyai nilai kekuatan tekan $(\mathrm{kg} / \mathrm{cm} 2)$ yang besar maka nilai $\mathrm{S} / \mathrm{NR}$ semakin

\begin{tabular}{|c|c|c|c|c|c|c|c|c|c|c|c|}
\hline \multirow{4}{*}{$\begin{array}{c}\text { Tinal No } \\
1 \\
\end{array}$} & \multirow{2}{*}{\multicolumn{7}{|c|}{ Faktor Terkendali }} & \multirow{3}{*}{\multicolumn{2}{|c|}{$\frac{\text { Hasil Uji }}{\text { Kuat Tekan }}$}} & \multirow{4}{*}{$\begin{array}{c}\text { Rata-natat } \\
50 \\
50\end{array}$} & \multirow{4}{*}{$\begin{array}{l}\text { SNR } \\
32,31 \\
\end{array}$} \\
\hline & & & & & & & & & & & \\
\hline & \multirow{2}{*}{$\begin{array}{l}B \\
1\end{array}$} & \multirow{2}{*}{$\begin{array}{l}E \\
1\end{array}$} & \multirow{2}{*}{$\begin{array}{c}\mathrm{BxE} \\
1 \\
\end{array}$} & \multirow{2}{*}{$\begin{array}{l}c \\
l\end{array}$} & \multirow{2}{*}{$\begin{array}{l}\mathrm{D} \\
1\end{array}$} & \multirow{2}{*}{\begin{tabular}{c|}
$C x D$ \\
1
\end{tabular}} & \multirow{2}{*}{$\frac{A}{1}$} & & & & \\
\hline & & & & & & & & 48 & 52 & & \\
\hline 2 & 1 & 1 & 1 & 2 & 2 & 2 & 2 & 56,25 & 58,5 & 57,375 & 33,46 \\
\hline 3 & 1 & 2 & 2 & 1 & 1 & 2 & 2 & 97,5 & 92 & 94,75 & 37,67 \\
\hline 4 & 1 & 2 & 2 & 2 & 2 & 1 & 1 & 82,5 & 91,25 & 86,875 & 37,13 \\
\hline 5 & 2 & 1 & 2 & 1 & 2 & 1 & 2 & 87,5 & 82,5 & 85 & 36,73 \\
\hline 6 & 2 & 1 & 2 & 2 & 1 & 2 & 1 & 72 & 68 & 70 & 35,05 \\
\hline 7 & 2 & 2 & 1 & 1 & 2 & 2 & 1 & 60 & 62 & 61 & 3399 \\
\hline 8 & 2 & 2 & 1 & 2 & 1 & 1 & 2 & 82,5 & 91 & 86,75 & 37,12 \\
\hline & & & & & Total & & & & & & 283,46 \\
\hline
\end{tabular}
baik. Nilai S/N untuk jenis karateristik HB adalah seperti pada tabel 9.

TABEL IX

Sumber : Pengolahan Data 2016

Dari hasil perhitungan di atas maka didapat perhitungan dalam menetukan efek tiap faktor kendali seperti yang tercantum tabel 10 .
TABEL $X$

TABEL RESPON UNTUK NILAI SNR ESKPERIMEN OPTIMAL

\begin{tabular}{|c|c|c|c|c|c|}
\hline & A & B & C & D & E \\
\hline Level 1 & 66,96875 & 72,25 & 72,6875 & 74,5313 & 65,5938 \\
\hline Level 2 & 80,96875 & 75,6875 & 75,25 & 75,375 & 82,3438 \\
\hline Selisih & 14 & 3,4375 & 2,5625 & 0,84375 & 16,75 \\
\hline Rangking & 2 & 3 & 5 & 4 & 1 \\
\hline
\end{tabular}

Sumber : Pengolahan Data 2016

Langkah yang sama dilakukan untuk perhitungan daya serap.

9. Grafik Main Effect Factor

Dalam menentukan faktor-faktor yang berpengaruh secara signifikan terhadap kualitas, dapat dilihat dalam grafik main effect factor.

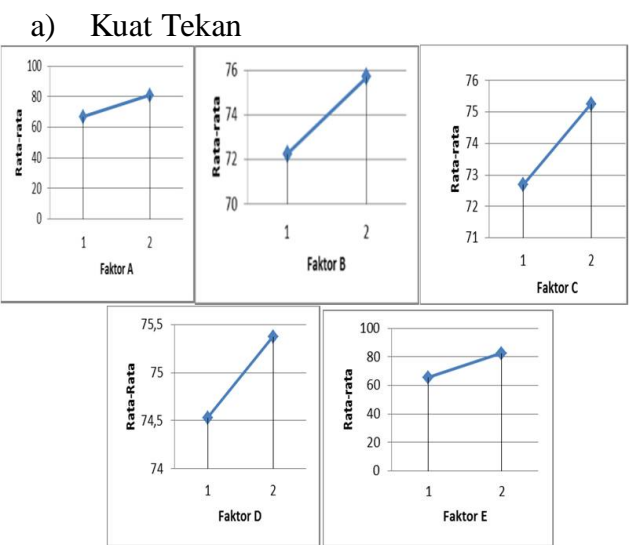

Gambar 5. Grafik Main Effect Factor Kuat Tekan

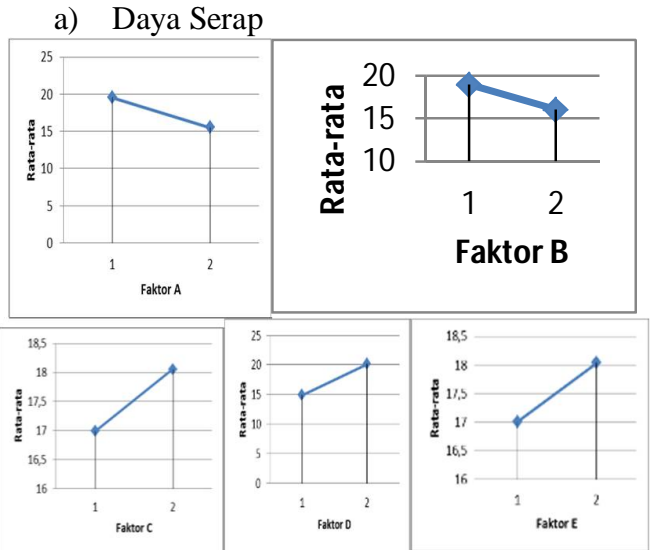

Gambar 6. Grafik Main Effect Factor Daya Serap

10. Analisis Hasil Eksperimen

Setelah melakukan perhitungan dengan menggunakan ANOVA, dan membut grafik main effect factor maka dapat diketahui setting level yang sesuai untuk meningkatkan kualitas batako pada tingkat mutu I antara lain: 
a) Kuat Tekan

Hasil setting level factor optimal untuk kuat tekan seperti yang tercantum pada tabel 11 .

TABEL XI

HASIL SETTING LEVEL FACTOR OPTIMAL KUAT TEKAN

\begin{tabular}{|l|c|c|}
\hline \multicolumn{1}{|c|}{ Faktor } & Level & Keterangan \\
\hline A Lama Pengadukan & 2 & 10 menit \\
\hline B Tekanan & 2 & $120 \mathrm{~kg}$ \\
\hline C Air & 2 & 15 \\
\hline D Pengeringan & 2 & 8 hari \\
\hline E Komposisi pasir dan kapur & 2 & $1 ; 0,25$ \\
\hline \multicolumn{2}{|l}{ Sumber : Pengolahan Data 2016 }
\end{tabular}

\section{b) Daya Serap}

Hasil setting level factor optimal untuk daya serap seperti yang tercantum pada tabel 12 .

TABEL XII

HASIL SETTING LEVEL FACTOR OPTIMAL DAYA SERAP

\begin{tabular}{|l|c|c|}
\hline \multicolumn{1}{|c|}{ Faktor } & Level & Keterangan \\
\hline A Lama Pengadukan & 2 & 10 Menit \\
\hline B Tekanan & 2 & $120 \mathrm{~kg}$ \\
\hline C Air & 1 & 10 \\
\hline D Pengeringan & 1 & 4 Hari \\
\hline E Komposisi pasir dan kapur & 1 & $1 ; 0,5$ \\
\hline
\end{tabular}

Sumber : Pengolahan Data 2016

\section{Eksperimen Konfirmasi}

Setelah melakukan perhitungan dengan menggunakan uji ANOVA maka dapat diketahaui setting level factor untuk masing-masing faktor, maka dilakukan percobaan konfirmasi dengan menggunakan setting level yang telah ditentukan, sehingga diperoleh hasil seperti yang tercantum pada tabel 13 .

TABEL XIII

DATA PERCOBAAN KONFIRMASI

\begin{tabular}{|c|c|c|}
\hline Percobaan & Kuat Tekan (Kg) & aya Serap (\% \\
\hline 1 & 75 & 9 \\
\hline 2 & 90 & 6 \\
\hline 3 & 82,5 & 10 \\
\hline 4 & 75 & 10 \\
\hline 5 & 78,5 & 7 \\
\hline 6 & 82,5 & 10 \\
\hline 7 & 82,5 & 12 \\
\hline 8 & 75 & 5 \\
\hline 9 & 75 & 11 \\
\hline 10 & 82 & 10 \\
\hline Rata-rata & $\mathbf{7 9 , 8}$ & $\mathbf{9 , 0}$ \\
\hline Standar Deviasi & $\mathbf{2 5 , 0}$ & $\mathbf{5 , 1}$ \\
\hline
\end{tabular}

Sumber : Pengolahan Data 2016

\section{Perhitungan Loss Function}

Perhitungan loss function dilakukan untuk mengetahui seberapa besar loss yang diperoleh perusahaan setelah menggunakan teknik/setting level baru. Maka dapat dilakukan perhitungan loss function seperti yang ercantum pada abel 14 .
TABEL XIV

\begin{tabular}{|c|c|c|c|c|c|c|c|c|}
\hline \multirow{3}{*}{ Sampel } & \multicolumn{2}{|c|}{ Data Histonk } & \multicolumn{2}{|c|}{ Loss Funcion Historik } & \multicolumn{2}{|c|}{ Data Histork } & \multicolumn{2}{|c|}{ Loss Function Konfirmasi } \\
\hline & Kuat Tekan & Daya Serap & Kuat Tekan & Daya Serap & $V_{0}$ & Donsenglol & KuatTekan & Daya Serap \\
\hline & $(\mathrm{Kg} / \mathrm{cm} 2)$ & (\%) & $(\mathrm{Kg} g \mathrm{~cm} 2)$ & (\%) & 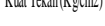 & Dajac elap pion & (Kg/cm2) & (\%) \\
\hline 1 & 45 & 19 & 0,00049383 & 0,0027701 & 75 & 9 & 0,00017778 & 0,0123457 \\
\hline 2 & 30 & 21 & 0,00111111 & 0,0022676 & 90 & 6 & 0,000123457 & 0,0277778 \\
\hline 3 & 34 & 15 & 0,00086605 & 0,0044444 & 82,5 & 10 & 0,000146924 & 0,01 \\
\hline 4 & 30 & 21 & 0,00111111 & 0,0022676 & 75 & 10 & 0,000177778 & 0,01 \\
\hline 5 & 34 & 19 & 0,00086505 & 0,0027701 & 78,5 & 7 & 0,000162278 & 0,0204082 \\
\hline 6 & 47,5 & 17 & 0,00044321 & 0,00334602 & 82.5 & 10 & 0,000146924 & 0,01 \\
\hline 7 & 45 & 13 & 0,00049383 & 0,0059172 & 82,5 & 12 & 0,00014624 & 0,0669444 \\
\hline 8 & 45 & 16 & 0,00044383 & 0,0039063 & 75 & 5 & 0,000177778 & 0.04 \\
\hline 9 & 38,2 & 19 & 0,00068529 & 0,0027701 & 75 & 11 & 0,00017778 & 0,0082645 \\
\hline 10 & 35 & 19 & 0,00081633 & 0,0027701 & 82 & 10 & 0,000148721 & 0,01 \\
\hline \multicolumn{3}{|c|}{ Loss Function } & 0,00737864 & 0,0333435 & & & 0,001586339 & 0,157405 \\
\hline
\end{tabular}

Dari hasil perhitungan dapat diketahui bahwa terjadi perubahan loss setelah menggunakan kombinasi level yang baru.

13. Perhitungan Persentase Perbaikan

Perhitungan Persentase Pebaikan sebagai berikut:

$$
\begin{gathered}
=\frac{(\text { rata }- \text { rata data konfirmasi })-(\text { rata }- \text { rata data historik })}{\text { rata }- \text { rata data konfirmasi }} \\
\text { - } \quad \begin{array}{l}
\text { Kuat Tekan } \\
=\frac{79,8-38,37}{79,8} \\
=51,91 \%
\end{array}
\end{gathered}
$$

Dari perhitungan diatas maka terjadi peningkatan kualitas kuat tekan batako sebesar 51,91\%

- Data penurunan tingkat kerugian

- $\frac{(\text { rata - rata data historik })-(\text { rata - rata data konfirmasi })}{\text { rata })}$

$=\frac{\text { rata }- \text { rata data historik }}{\text { rata }}$

$=\frac{0,001586339-0,00737864}{0,001586339}=78,5 \%$

Dari perhitungan ditas maka disimpulkan penurunan loss function sebesar $78,5 \%$.

\section{Penentuan Responden}

Terdapat 50 responden yang digunakan dalam pengisian kuesoner ini. Setelah dilakukan hasil perhitungan menggunakan slovin maka hasil yang di dapat adalah sebanyak 45 responden.

Uji kecukupan data dilakukan dengan menggunakan Slovin yang digunakan untuk menghitung ukuran sample dengan jumlah populasi (N) dan error (e). Ini adalah teknik random sampling untuk mengetahui ukuran sample dengan rumus :

$$
n=\frac{N}{1+N e^{2}}
$$




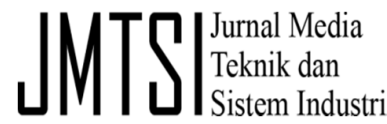

$=\frac{50}{1+N e^{2}}$

$=\frac{50}{1+\left(50 * 0.05^{2}\right)}=44.444$ Dibulatkan menjadi 45

Uji validitas dalam penelitian ini menggunakan bantuan Software SPSS 12 for windows. Uji signifikansi dilakukan dengan membandingkan nilai $\mathrm{r}$ hitung dengan $\mathrm{r}$ table untuk degree of freedom $(d f)$ dengan rumus :

$$
\begin{aligned}
d f & =n-2 \\
& =45-2 \\
& =43
\end{aligned}
$$

\begin{tabular}{|c|c|c|c|c|}
\hline & No & Pernyataan & R Hitung & Keterangan \\
\hline \multirow{4}{*}{$\frac{\sqrt{2}}{2}$} & 1 & $\begin{array}{l}\text { Dimensi batako yang } \text { dihasilkan } \\
\text { sesuai dengan SNI (Standar Nasional } \\
\text { Indonesia S-04-1989) }\end{array}$ & 0.471 & Valid \\
\hline & 2 & $\begin{array}{l}\text { Berat batako sesuai dengan } \\
\text { (Standar Nasional Indonesia) }\end{array}$ & 0.496 & Valid \\
\hline & 3 & $\begin{array}{l}\text { Tingakat kekerasan batako sesuai } \\
\text { dengan (Standar SNI 03-0349-1989) }\end{array}$ & 0.517 & Valid \\
\hline & 4 & $\begin{array}{l}\text { Daya serap yang dihasilkan sesuai } \\
\text { (SNI 03-0349-1989) }\end{array}$ & 0.432 & Valid \\
\hline & 5 & $\begin{array}{l}\text { Kandungan kadar air pada batako } \\
\text { sesuai dengan (Standar SNI 03-0349- } \\
1989 \text { ) }\end{array}$ & 0.406 & Valid \\
\hline & 6 & $\begin{array}{l}\text { Komposisi pasir,kapur dan air sesuai } \\
\text { dengan aturan pabrik }\end{array}$ & 0.396 & Valid \\
\hline & 7 & $\begin{array}{lrr}\begin{array}{l}\text { Perbandingan } \\
\text { sesuai dengan aturan pabriki }\end{array} & \text { batako }\end{array}$ & 0.499 & Valid \\
\hline 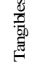 & 8 & $\begin{array}{l}\text { Permukaan batako tida memiliki } \\
\text { rongga dan tampak halus }\end{array}$ & 0.478 & Valid \\
\hline \multirow{2}{*}{ 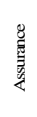 } & 10 & $\begin{array}{l}\text { Harga batako merk wess terjangkau } \\
\text { oleh konsumen }\end{array}$ & 0.418 & Valid \\
\hline & 11 & $\begin{array}{l}\text { Harga yang ditawarkan sesuai dengan } \\
\text { kualitas yang diharapkan }\end{array}$ & 0.422 & Valid \\
\hline \multirow{2}{*}{$\frac{\mathscr{y}_{0}}{\frac{8}{8}}$} & 12 & $\begin{array}{l}\text { Pelayanan pengiriman batako sesuai } \\
\text { dengan harapan }\end{array}$ & 0.563 & Valid \\
\hline & 13 & $\begin{array}{l}\text { Pelanggan merasa puas dengan batako } \\
\text { yang dihasilkan di pabrik WS }\end{array}$ & 0.528 & Valid \\
\hline
\end{tabular}

TABEL XIV

HASIL UJI VALIDITAS

Perhitungan reliabilitas menggunakan software SPSS12 menunjukan bahwa kuesioner penelitian terbukti dapat diandalkan dengan nilai $\alpha$ cronbach's $>0,7$.

\section{Evaluasi Kano}

Hasil pemetaan kategori kano seperti yang tercantum pada tabel 15, sedangkan hasil kategori kano tercantum pada tabel 16. Tabel 17 menunjukan hasil pemetaan model kano berdasarkan SERVQUAL.
TABEL XV

PemetaAn Kategori Kano

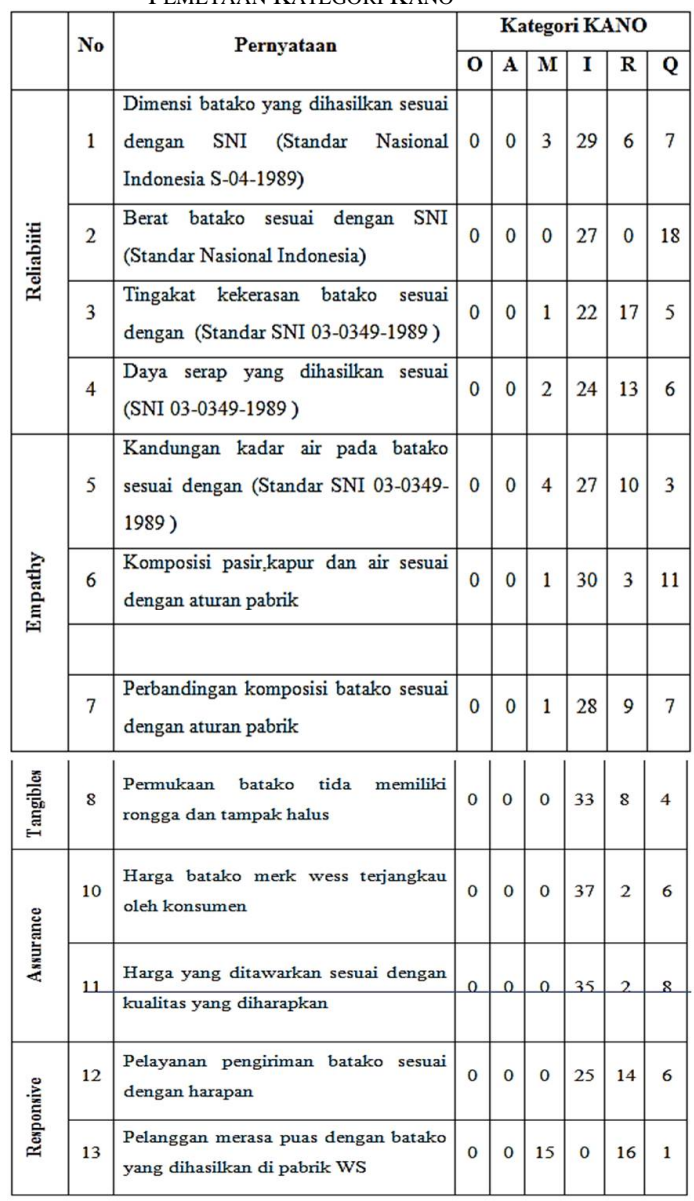

\begin{tabular}{|c|c|c|c|}
\hline & No & Pernyataan & $\begin{array}{c}\text { Kategori } \\
\text { Kano }\end{array}$ \\
\hline \multirow{4}{*}{ 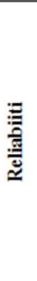 } & 1 & $\begin{array}{l}\text { Dimensi batako yang dihasilkan sesuai dengan } \\
\text { SNI (Standar Nasional Indonesia S-04-1989) }\end{array}$ & I \\
\hline & 2 & $\begin{array}{l}\text { Berat batako sesuai dengan } \text { SNI (Standar } \\
\text { Nasional Indonesia) }\end{array}$ & I \\
\hline & 3 & $\begin{array}{l}\text { Tingakat kekerasan batako sesuai dengan } \\
\text { (Standar SNI 03-0349-1989) }\end{array}$ & I \\
\hline & 4 & $\begin{array}{l}\text { Daya serap yang dihasilkan sesuai (SNI 03-0349- } \\
1989 \text { ) }\end{array}$ & I \\
\hline 产 & 5 & $\begin{array}{l}\text { Kandungan kadar air pada batako sesuai dengan } \\
\text { (Standar SNI 03-0349-1989) }\end{array}$ & I \\
\hline
\end{tabular}

TABEL XVI

HASIL KATEGORI KANO 


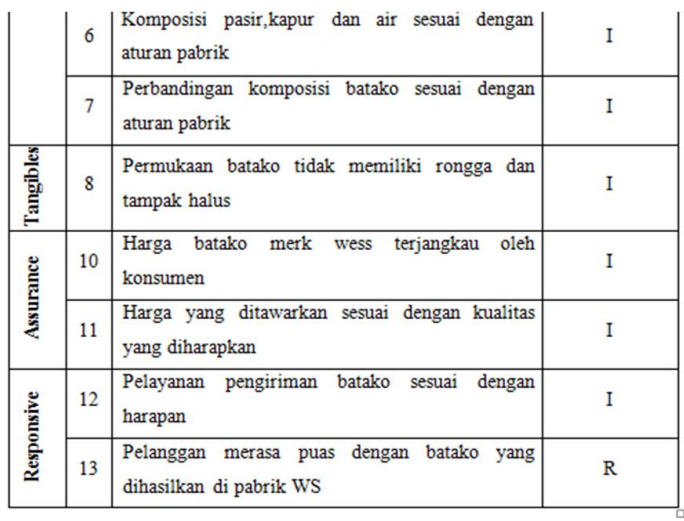

TABEL XVII

PEMETAAN MOdEl KANO BERDASARKAN SERVQUAL

\begin{tabular}{|c|c|c|c|c|c|c|c|}
\hline No & Dimensi Servqual & $\mathbf{O}$ & $\mathbf{A}$ & $\mathbf{M}$ & $\mathbf{I}$ & $\mathbf{R}$ & $\mathbf{Q}$ \\
\hline 1 & Reliability & 0 & 0 & 6 & 102 & 36 & 36 \\
\hline 2 & Responsive & 0 & 0 & 15 & 25 & 30 & 7 \\
\hline 3 & Assurance & 0 & 0 & 0 & 72 & 4 & 14 \\
\hline 4 & Empati & 0 & 0 & 6 & 85 & 22 & 21 \\
\hline 5 & Tangibles & 0 & 0 & 0 & 33 & 8 & 4 \\
\hline
\end{tabular}

\section{KESIMPULAN}

Berdasarkan hasil pengolahan dan analisis data maka diperoleh kesimpulan bahwa hasil penelitian taguchi sebagai input untuk penelitian sekarang. Pada penelitian sebelumnya hasil kualitas batako dengan menggunakan metode taguchi mengalami peningkatan kualitas untuk kuat tekan dan daya serap. Tabel 18 menunjukan data uji kuat tekan dan daya serap kondisi aktual.

TABEL XVIII

Data Awal KuAT TEKAN DAN DAYa SERAP

\begin{tabular}{|c|c|c|}
\hline Percobaan & Kuat Tekan $($ Kg) & Daya Se rap (\%) \\
\hline 1 & 45 & 19 \\
\hline 2 & 30 & 21 \\
\hline 3 & 34 & 15 \\
\hline 4 & 30 & 21 \\
\hline 5 & 34 & 19 \\
\hline 6 & 47,5 & 17 \\
\hline 7 & 45 & 13 \\
\hline 8 & 45 & 16 \\
\hline 9 & 38,2 & 19 \\
\hline 10 & 35 & 19 \\
\hline Rata-rata & $\mathbf{3 8 , 3 7}$ & $\mathbf{1 7 , 9}$ \\
\hline Standar De viasi & $\mathbf{4 5 , 0}$ & $\mathbf{6 , 8}$ \\
\hline
\end{tabular}

TABEL XIX

DATA HASIL PERCOBAAN KONFIRMASI

\begin{tabular}{|c|c|c|}
\hline Percobaan & Kuat Tekan (Kg) & Daya Serap (\%) \\
\hline 1 & 75 & 9 \\
\hline 2 & 90 & 6 \\
\hline 3 & 82,5 & 10 \\
\hline 4 & 75 & 10 \\
\hline 5 & 78,5 & 7 \\
\hline 6 & 82,5 & 10 \\
\hline 7 & 82,5 & 12 \\
\hline 8 & 75 & 5 \\
\hline 9 & 75 & 11 \\
\hline 10 & 82 & 10 \\
\hline Rata-rata & $\mathbf{7 9 , 8}$ & $\mathbf{9 , 0}$ \\
\hline Standar Deviasi & $\mathbf{2 5 , 0}$ & $\mathbf{5 , 1}$ \\
\hline
\end{tabular}

Sumber : Pengolahan Data 2016

\section{Model kano}

- Berdasarkan dimensi Reliabilitas hasil perhitungan model kano, dimensi reliability yang menunjukan bahwa dimensi, berat, tingkat kekerasan dan daya serap batako berada pada level I (Indiferent) yang berarti netral, hal ini menunjukan bahwa berdasarkan dimensi reliability kualitas batako WS sudah bagus namun akan lebih bagus bila ditingkatkan lagi.

- Pada dimensi empati hasil perhitungan kano menunjukan bahwa kandungan, komposisi dan perbandingan bahan untuk pembuatan batako berate pada level I (Indiferent) yang berarti netral, hal ini menunjukan bahwa berdasarkan dimensi empati kualitas batako yang dihasilkan berdasarkan kandungan bahan yang digunakan sudah baik.

- Pada dimensi tangibles hasil perhitungan kano menunjukan bahwa hasil permukaan batako dengan permukaan yang tidak memiliki rongga berada pada level I (Indiferent) yang berarti netral, hal ini menunjukan bahwa kualitas batako yang dihasilkan berdasarkan bentuk permukaan yang diperoleh sudah baik.

- Pada dimensi Assurance hasil perhitungan kano menunjukan bahwa harga yang diperoleh pada penjualan batako menunjukan level I (Indiferent) yang berarti netral, hal ini menunjukan bahwa harga yang di peroleh terjangkau oleh pembeli.

- Pada dimensi responsive hasil perhitungan model kano menunjukan pelayanan, dan tingkat kepuasan konsumen terhadap kualitas batako berada pada level R (Reverse) yang berarti kemunduran, pada tingkat ini bahwa kualitas atas batako yang dihasilkan perlu ditingkatkan. 


\section{JMTSl|ciantiate}

\section{REFERENSI}

[1] Aritonang R. [2005], Kepuasan Pelanggan: Pengukuran dan Penganalisisan dengan SPSS, Penerbit PT. Gramedia, Jakarta

[2] Irawan Handi, [2002], 10 Prinsip Kepuasan Pelangggan, Penerbit Elex Media Komputindo, Jakarta.

[3] Parasuraman A, Zeithmanl, Valarie \& Berry, Leonard L (1988), Servqual : A Multiple-Item Scala for Measuring Consumer Perceptions of Service Quality, Journal of Retailing, Vol 64, No. 1 Spring.

[4] Tjiptono, Fandy (2000). Manajemen Jasa Edisi III, ISBN : 979-533767-X, Penerbit Andi yogyakarta

[5] Fandy Tjiptono, (1997). Total Quality Service, Gramedia, Yogyakarta.

[6] Tjiptono, Fandy ; Chandra, Gregorius (1998), Service, Qualty, Statisfaction, Penerbit Andy Yogyakarta.

[7] Yamit, Zulian. (2005). Manajemen Kualitas Produk dan Jasa. Edisi pertama, cetakan keempat, penerbit Ekonosia.

[8] Tjiptono. (2005). Strategi Kualitas Jasa/Layanan. No 132, Andi Offset, Yogyakarta

[9] Tjiptono, Fandi. 2005. Pemasaran Jasa. Yogyakarta : Andi Offset.

[10] Tjiptono, Fandi. 2001. Strategi Pemasaran. Yogyakarta : Andi Offset.

[11] Jurnal Rudy Wawolumaja dan Ridani Faurika. Penerapan Taguchi Parameter Design dalam Penentuan Level Faktor Produksi Batako untuk Memaksimumkan Kekuatan Tekan (Studi Kasus di Balai Besar Keramik).

[12] Kotler, 2004 Ten Deadly Marketing Sins, Penerbit Erlangga, Jakarta.

[13] Rangkuty, Freddy, 1997, Riset Pemasaran, Penerbit : PT. Gramedia Pustaka Utama, Jakarta

[14] Schiffiman, Leon, 2004, Perilaku Konsumen, Penerbit: PT. Indeks. 